\title{
Sexual stages of the female portion in the scallop Nodipecten nodosus (Linné, 1758) and astaxanthin quantity in each stage
}

\author{
Sühnel, $S{ }^{\text {a* }}$, Lagreze, $F^{\text {a }}$, Bercht, $M .^{\text {a }}$, Ferreira, $J F^{\text {a }}$, \\ Carneiro-Schaefer, AL. ${ }^{\mathrm{b}}$, Magalhães, ARM. ${ }^{\mathrm{b}}$ and Maraschin, $M .^{\mathrm{c}}$ \\ aLaboratório de Moluscos Marinhos, Universidade Federal de Santa Catarina - UFSC, \\ Servidão dos Coroas, s/n, Barra da Lagoa, CEP 88061-600, Florianópolis, SC, Brazil

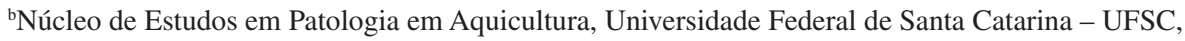 \\ Rodovia Edmar Gonzaga, 1346, Itacorubi, CEP 88040-900, Florianópolis, SC, Brazil \\ 'Laboratório de Morfogênese e Bioquímica Vegetal, Universidade Federal de Santa Catarina - UFSC, \\ Rodovia Admar Gonzaga, 1346, Itacorubi, CEP 88040-900, Florianópolis, SC, Brazil, \\ *e-mail ssuhnel@gmail.com
}

Received July 25, 2008 - Accepted October 28, 2009 - Distributed August 31, 2010

(With 3 figures)

\begin{abstract}
This work describes the gametogenic cycle of the scallop Nodipecten nodosus kept in a culture system. To this end, during one year, samples were taken from the broodstocks every 30 days to be submitted to macroscopic and microscopic analyses and to measure the amount of astaxanthin. To perform the microscopic evaluation, $5 \mu$ slices from the median portion of the female part of the gonad were submitted to the pattern methodology for histological analyses with paraffin and HE coloration. The remaining portion of the female gonad was lyophilised to extract and quantify the levels of astaxanthin using HPLC. The microscopic analyses revealed four well defined stages for the reproductive cycle. Analyses of data taken throughout the year indicated preferential spawning periods from December to January and from July to September. The astaxanthin analyses showed higher amounts of this carotenoid during the advanced pre-spawning and the initial spawning periods than during gametogenesis, initial pre-spawning, advanced spawning, and the spent stages. According to these results, it was possible to establish a descriptive table of the sexual stages of the female portion of the gonad and the amount of astaxanthin in the sexual stage of the scallop Nodipecten nodosus.
\end{abstract}

Keywords: reproductive cycle, astaxanthin, Nodipecten nodosus, scallop gonadic maturation.

\section{Estágios sexuais da porção feminina da gônada da vieira Nodipecten nodosus (Linné, 1758) e a quantidade de astaxantina em cada estágio}

\section{Resumo}

Este trabalho descreve o ciclo gametogênico da vieira Nodipecten nodosus mantida em ambiente de cultivo. Para isto, durante um ano, amostras de indivíduos reprodutores foram coletadas a cada 30 dias e submetidas à avaliação macroscópica e microscópica e à quantificação de astaxantina. Para a avaliação microscópica, secções de $5 \mu$ da porção mediana feminina da gônada foram submetidas à metodologia de análise histológica padrão em parafina e coloração HE. O restante da porção feminina da gônada foi liofilizado para extração e quantificação de astaxantina em HPLC. A avaliação microscópica permitiu a descrição de quatro estágios bem definidos para o ciclo reprodutivo. Na análise ao longo do ano, foram observados períodos preferenciais de desova em dezembro e janeiro e de julho a setembro. A análise da quantidade de astaxantina, mostrou, nos estádios de pré-desova avançada e de desova inicial, uma maior quantidade desse carotenoide em comparação aos estádios de gametogênese, pré-desova inicial, desova avançada e repouso. Em função desses resultados, foi possível estabelecer um quadro descritivo dos estágios sexuais da porção feminina da gônada e quantidade de astaxantina em cada estágio sexual da vieira Nodipecten nodosus.

Palavras-chave: ciclo reprodutivo, astaxantina, Nodipecten nodosus, maturação gonádica de vieira. 


\section{Introduction}

The world production of pectens, a bivalve mollusks, in 2007, was $12,616,738 \mathrm{t}$, generating 11,740,962 dollars (FAO, 2009).

Along the Brazilian coast, the Pectinidae family is represented by 4 genera and 14 species (Rios, 2009). Of these 14 species, Nodipecten nodosus (Linné, 1758) stands out as a species of economic value in Brazil. According to Manzoni and Rupp (1993), N. nodoss has significant potential for culture in the natural environment due to fast growth and large adult size (Rupp et al., 2004; Rupp and Parsons, 2006). The high market price is another factor that is of interest for culture. Scallops have been offered not only in sophisticated Brazilian restaurants but also all around the world, including in haute cuisine. Almost all scallops consumed in Brazil come from abroad; this is the main reason why the study of its biology, reproductive cycle, culture and other factors are of great importance for its production.

In 2007, there were about 24 thousand units of scallops produced in Santa Catarina (EPAGRI, 2008). It thus represents a new source of income for the fishers who before, depended only on fishing. The cultivation of the native species of scallops, Nodipecten nodosus, represents an advantage for cuisine and tourism, for being very tasty.

The knowledge of the reproductive cycle of Nodipecten nodosus is fundamental for the production of scallop seeds in the laboratory.

The bivalve mollusc $N$. nodosus is a functional (simultaneous) hermaphrodite (Rupp, 1994; Lodeiros et al., 1997; Freitas, 2001). Adult animals in their natural environment spawn throughout the year, with periods of higher intensity concentrated in spring and summer around Arvoredo Island, Southern Brazil (Manzoni, 1994; Manzoni et al., 1996).

Research on N. nodosus spats settlements, using artificial collectors in the natural environment, has demonstrated that this species has a low rate of settlement, due to the low density and high dispersion of the populations (Ostini and Poli, 1990; Manzoni and Rupp, 1993; Manzoni et al., 1996). These data, combined with asynchronous spawning, suggest that the seed supply of this species for commercial production would be viable through hatchery production rather than extraction from its natural habitat.

One of the factors that affects seed production is the maturation stage of the female portion of the gonad to be used for spawning. This differentiation is therefore very relevant for commercial hatchery production. Lubet (1959), identified several different phases of the reproductive cycle of bivalve molluscs through the observation of histological sections of the gonad. Repeating this analysis for N. nodosus, we also identified different phases of gonad maturation, described later in this paper.

$N$. nodosus is characterised by one well defined gonad surrounded by tegumentum. The tegumentum is composed of an external epithelium, a basal lamina and connective tissue (sub-epithelial perigonadic tissue). The gonad contains gonoducts, blood vessels, muscle fibre and part of the intestine. The white male portion of the gonad is proximate and the orange female portion is distal. The follicles have a bulb-like shape and are delineated by connective interstitial tissue that is thin when the follicles are filled with gametes and more evident and enlarged when the follicles are empty. The tubular gonoducts link the follicle to the external side and are formed by a simple prismatic epithelium. The gametes leave the paleal cavity through the urogenital pore (Román et al., 2001).

Sühnel et al. (2009) observed that the N. nodosus pectinid contains an unusually large amount of carotenoids in the female portion of the gonad. The present study quantifies the accumulation of astaxanthin in the female portion of the gonad of $N$. nodosus broodstock in each sexual stage, and provides a histological description of these different stages based on observation of individuals produced in the hatchery over the period of one year. The relation between astaxanthin levels and the reproductive stages is also evaluated.

\section{Material and Methods}

Nodipecten nodosus (Linné, 1758) scallop broodstock were collected from the EPAGRI (Empresa de Pesquisa Agropecuária e Extensão Rural/Rural Extension and Agronomic Research Company) experimental culture area, at Canto Grande beach near Bombinhas (27 $12^{\prime}$ '5.39' S and $48^{\circ} 30^{\prime} 47.7^{\prime \prime} \mathrm{N}$ ) in the State of Santa Catarina, Southern Brazil. High Performance Liquid Chromatography (HPLC) for carotenoids analyses were carried out at the Laboratory of Plant Morphogenesis and Biochemistry/ UFSC (Universidade Federal de Santa Catarina), and histological analyses were carried out at the Aquaculture Pathology Studies Nucleus/UFSC.

\subsection{Experimental design}

For the description of the female gametogenic cycle 45 animals of $70 \pm 5 \mathrm{~mm}$ in height, 1.5 years of age, were collected from the EPAGRI research area. The amount of astaxanthin was quantified in histological sections of the female part of the gonad.

To describe the reproductive cycle over the year, approximately 70 individuals of $70 \pm 5 \mathrm{~mm}$ in height and 1.5 years old, from the same spawning group (30 adults), were kept in a lantern net in a long line at the experimental area of EPAGRI, and 4 individuals were collected each month for determination of maturation stage.

After collection, the animals, with their valves shut, were immediately transported in polystyrene boxes to the laboratory. At the laboratory, a sexual macroscopic evaluation was carried out, and scissors and a scalpel were used to remove the female portion of the gonads. The tissues removed were desalinated by washing, at room temperature, with a solution of ammonium formiate $(0.5 \mathrm{M})$. The excess liquid from the sample gonadal tissue was removed using blotting paper. For the histological procedures, the female portion of the gonad was divided into two portions with 
a central longitudinal cut and one section was used for the histological analysis. The other half, used for the astaxanthin analysis, was stored at $-18{ }^{\circ} \mathrm{C}$ for 24 hours and then lyophilised (Terroni Favel LT 1000/8).

\subsection{Histology}

The sectioned gonadal tissues were fixed in a Davidson's solution and stored in 70\% Ethanol. After 6 Ethanol (from $70-100 \%$ ) and Xhylol baths, they were embedded with paraffin.

The blocks containing the gonad samples were cut into $5 \mu$-thick slices and coloured with Harris's Hematoxylin and Eosin.

The identification of the reproductive stages involved two independent evaluations with the aid of a microscope, carried out by two different persons, without previous identification of the slide, enlarged to 200 and 400x.

To define the reproductive stage, a score system was developed for each stage, with values from 1 to 6 (Table 1), which was compared using statistical analyses. The different reproductive stages were defined according to their histological characteristics.

The sea-water temperature was recorded between October 2006 and November 2007 in the long line where the animals were kept using a TidBit (Optic StowAwayTEMP) installed at the culture area.

\subsection{Astaxanthin analysis}

Carotenoid extraction followed the methodology described in Sühnel et al. (2009). The lyophylised sample was placed in a ceramic container with liquid nitrogen, mixed and $50 \mathrm{mg}$ were removed. To this sample, we added $5 \mathrm{~mL}$ of acetone extracting solution (Ac $=\mathrm{O}$, Nuclear, P.A.) and $n$-hexane (Hex, TediaBrazil, P.A.) in a proportion of $1: 3$ respectively, and agitated it in a magnetic agitator Fisatom. Thus treated, the samples were kept at room temperature $\left(23^{\circ} \mathrm{C}\right)$ away from light during extraction. After extraction, the samples were filtered through filter paper, their final volume was adjusted to $3 \mathrm{~mL}$, and they were then stored in amber flasks in an $\mathrm{N}_{2}$ atmosphere. The samples were stored in a freezer $\left(-18^{\circ} \mathrm{C}\right)$ for subsequent determination of astaxanthin levels.

The astaxanthin was measured using HPLC. The methodology used for the analysis is described in Sühnel et al. (2009), where $300 \mu \mathrm{L}$ of the carotenoid extracts were filtered $(0.22 \mu$ filter $)$, and $10 \mu \mathrm{L}$ of each sample was injected in a liquid chromatograph (Shimzadu LC - 10A), equipped with a $\mathrm{C}_{18}$ column of reverse phase Vydac (BioRad, $25 \mathrm{~cm} \times 4.6 \mathrm{~mm}$

Table 1. Histological description of the female portion of the gonad stages in the reproductive cycle of the scallop Nodipecten nodosus.

\begin{tabular}{|c|c|c|c|c|}
\hline Stage & $\begin{array}{c}\text { Stage } \\
\text { No. }\end{array}$ & $\begin{array}{l}\text { No. of } \\
\text { points }\end{array}$ & $\begin{array}{l}\text { Microscopic } \\
\text { description }\end{array}$ & $\begin{array}{c}\text { Macroscopic } \\
\text { description }\end{array}$ \\
\hline Gametogenesis & 1 & 1 & $\begin{array}{l}\text { Few oocytes; Different sizes of oocytes; } \\
\text { Heterogeneous aspect; Presence of inter- } \\
\text { follicle tissue; Non-juxtaposed follicle } \\
\text { walls; Thicker follicle wall (presence of } \\
\text { internal oogonia); With empty inter-follicle } \\
\text { and intra-follicle spaces. }\end{array}$ & $\begin{array}{l}\text { Deflated gonad; } \\
\text { Pale Orange coloration; } \\
\text { Visible granules. }\end{array}$ \\
\hline $\begin{array}{l}\text { Initial } \\
\text { pre-spawning }\end{array}$ & $2 \mathrm{~A}$ & 2 & $\begin{array}{l}\text { Many follicles; Follicles full of gametes; } \\
\text { Elongated oocytes; } \\
\text { Clear but recognisable follicle walls; } \\
\text { Empty tube. }\end{array}$ & $\begin{array}{l}\text { Swollen gonad; } \\
\text { Bright orange } \\
\text { coloration; } \\
\text { No granules present. }\end{array}$ \\
\hline $\begin{array}{l}\text { Advanced } \\
\text { pre-spawning }\end{array}$ & $2 \mathrm{~B}$ & 3 & $\begin{array}{l}\text { More oocytes per follicle than in } 2 \mathrm{~A} \text {; } \\
\text { Extremely long and elongated oocytes; } \\
\text { Very juxtaposed and not clearly visible } \\
\text { follicle walls; Many follicles; Empty tube; } \\
\text { Slight stimulus or cut releases gametes; No } \\
\text { empty inter-follicle or intra-follicle spaces. }\end{array}$ & \\
\hline $\begin{array}{l}\text { Initial } \\
\text { spawning }\end{array}$ & $3 \mathrm{~A}$ & 4 & $\begin{array}{l}\text { Initial phase of gamete elimination; } \\
\text { Visible and not completely juxtaposed } \\
\text { follicle walls; Possible presence of gametes } \\
\text { in the genital tubes; Intra-follicle and inter- } \\
\text { follicle empty spaces. }\end{array}$ & $\begin{array}{l}\text { Swollen gonad; } \\
\text { Bright orange } \\
\text { coloration; } \\
\text { Granules present. }\end{array}$ \\
\hline $\begin{array}{l}\text { Advanced } \\
\text { spawning }\end{array}$ & 3B & 5 & $\begin{array}{l}\text { Empty follicles present; Irregularly } \\
\text { formed follicle due to recent spawning; } \\
\text { Completely or partially empty follicle; } \\
\text { Few remaining gametes. }\end{array}$ & \\
\hline Spent & 4 & 6 & $\begin{array}{l}\text { Few follicles; Remaining follicles have } \\
\text { small diameter; Abundant inter-follicle } \\
\text { connective tissue. }\end{array}$ & $\begin{array}{l}\text { Deflated gonad; } \\
\text { Pale orange; opaque; } \\
\text { No granules present. }\end{array}$ \\
\hline
\end{tabular}


$\varnothing)$ and UV-visible detector, operating with a reading of $470 \eta \mathrm{m}$. A solution of acetonitrile and methanol (at a 90:10 proportion, TediaBrazil, HPLC degree) with a $0.8 \mathrm{~mL} / \mathrm{min}$ flow was used as a mobile phase.

Astaxanthin was identified based on the period of retention obtained from the analysis of the standard sample

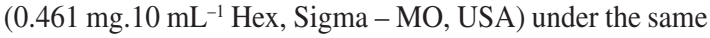
experimental conditions, and was measured by calculating the whole area of the corresponding peaks and applied to the external standard curve $\left(y=7044.96 \times, r^{2}=0.994\right)$.

\subsection{Statistical analyses}

The descriptive analysis of the astaxanthin levels in the female portion of the gonad and the reproductive cycle (using the points in Table 1, for each reproductive stage) was performed. As samples were not homogeneous, the evaluation of normality of error and homogeneity of variance (Barttlet) was applied using a non-parametric Kruskal-Wallis analysis followed by the Mann-Whitney U-test separation of two-by-two averages. The reference consulted for the statistical analyses was Zar (1974).

\section{Results}

\subsection{Description of reproductive stages}

The description of morphological aspects of the female gonadal portion was based on the observation of: (a) the macroscopic aspects: coloration, granulation and appearance of the gonad; and (b) the microscopic aspects: the aspects of oocytes, follicle walls, inter and intra follicular spaces, tube (gonoduct), connective tissue and disintegration of the gametes. The reproductive stages were classified into four stages (Figure 1, Table 1): (i) Stage 1 - gametogenesis; (ii) Stage 2A - initial pre-spawning and Stage 2B - advanced pre-spawning; (iii) Stage 3A - initial spawning and Stage 3B advanced spawning; and (iv) Stage 4 - spent.

Gametogenesis stage (Stage 1) is characterised by the presence of visible follicles with thick non-juxtaposed walls, containing few oocytes of different size and heterogeneous appearance. It is also possible to observe the oogonias in the luminal side of the follicle, the presence of inter-follicle connective tissue, and inter-follicle and intra-follicle empty spaces.

The initial pre-spawning stage (Stage 2A) is characterised by numerous follicles, which are filled with gametes, elongated oocytes, and clearly visible and recognisable follicle walls. The gonoducts have no oocytes (empty tube) and no inter-follicle and intra-follicle spaces are observed.

The stage of advanced pre-spawning (Stage 2B) is characterised by a much larger number of oocytes per follicle than in Stage 2A, extremely elongated oocytes, follicle walls that are very juxtaposed and hard to see, with many follicles. Gonoducts have no oocytes (empty tubes), and no empty intra-follicle and inter-follicle spaces are observed. As the gonad is filled with gametes, the medial cut applied for histological preparation stimulates their liberation.
The initial spawning stage (Stage 3A) is characterised as the initial phase of gamete liberation. The follicle walls are not completely juxtaposed, but still recognisable; there may be gametes in the genital tubes and intra-follicle and inter-follicle empty spaces can be observed.

The advanced spawning stage (Stage 3B) is characterised by empty and irregularly-shaped follicles, as a result of the recent spawning. At this stage, the follicles may be completely or partially empty, with few visible remaining oocytes.

The spent stage (Stage 4) is characterised by just a few remaining follicles, which are small in diameter and have abundant inter-follicle connective tissue.

\subsection{Variation of the reproductive stages in the culture tank}

The histological analysis of gonads from animals collected between November 2006 and November 2007 indicated two major spawning periods from December 2006 to January 2007, and from July to September 2007 in Canto Grande (South of Brazil). During the remaining months, the analysed animals were predominantly in the pre-spawning stage (Figure 2).

Seawater temperature between December 2006 and January 2007 varied from $22.64 \pm 0.77^{\circ} \mathrm{C}$ to $24.75 \pm 0.97{ }^{\circ} \mathrm{C}$, respectively; and in July, August and September 2007 average temperatures were $15.84 \pm 1.40{ }^{\circ} \mathrm{C}, 16.47 \pm 1.09{ }^{\circ} \mathrm{C}$ and $19.65 \pm 1.37^{\circ} \mathrm{C}$, respectively (Figure 2 ).

\subsection{Astaxanthin quantity at each reproductive stage}

To evaluate the carotenoid quantity in each reproductive stage (Figure 3) the homogeneity of the samples was verified. A Mann-Whitney U-Test comparing pairs of samples was then carried out to identify which stages differed significantly from others. Results indicated that astaxanthin levels in the advanced pre-spawning Stages 2B (45.06 $\left.\pm 6.35 \mu \mathrm{g} \cdot \mathrm{mL}^{-1}\right)$ and initial spawning $3 \mathrm{~A}\left(38.01 \pm 7.16 \mu \mathrm{g} \cdot \mathrm{mL}^{-1}\right)$ have no significant differences, but when gametogenesis 1 $\left(8.31 \pm 0.41 \mu \mathrm{g} . \mathrm{mL}^{-1}\right)$, initial pre-spawning $2 \mathrm{~A}(17.71 \pm$ $\left.4.87 \mu \mathrm{g} \cdot \mathrm{mL}^{-1}\right)$, advanced spawning 3B $\left(17.12 \pm 0.85 \mu \mathrm{g} \cdot \mathrm{mL}^{-1}\right)$, and spent $4\left(6.76 \pm 0.91 \mu \mathrm{g} . \mathrm{mL}^{-1}\right)$ are compared a significant difference is observed $(\mathrm{p}<0.05)$. The gametogenesis 1 and spent 4 stages are significantly different $(p<0.05)$ both from each other and from the other stages $(\mathrm{p}<0.05)$. The stages of initial pre-spawning $2 \mathrm{~A}$ and advanced spawning $3 \mathrm{~B}$ showed no significant differences.

\section{Discussion}

The gonad development phase can be identified by visually inspecting the gonad (macroscopic evaluation) considering size, colour and width; however, this method can lead to subjective estimates. An alternative direct method of identification is the gonadic index; this is achieved by dividing the drained weight of the gonad by the drained weight of the total weight of the soft tissues. While this method is simple and functional, its drawback is that the animal is sacrificed (Román et al., 2001). 

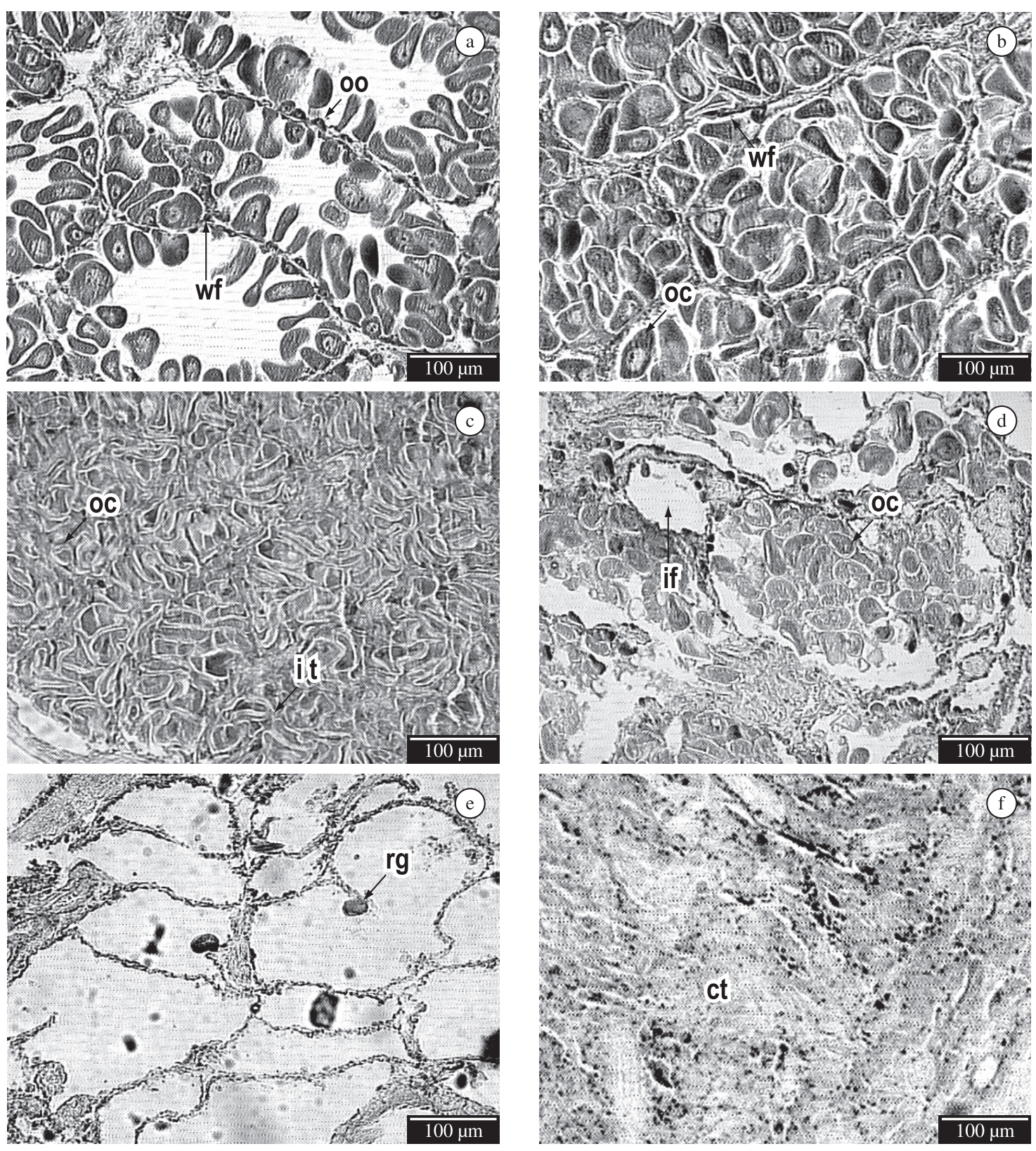

Figure 1. Histological sections of Nodipecten nodosus female gonad showing the different stages of the reproductive cycle: (a) gametogenesis; (b) initial pre-spawning; (c) advanced pre-spawning; (d) initial spawning; (e) advanced spawning; (f) spent. ct: connective tissue; oo: oogonia; wf: wall follicles; oc: oocytes; if: intra-follicle space; it: inter-follicular space (few); rg: remaining gametes. The bar represents 100 micra.

Notwithstanding these methods, the histological method (microscopic evaluation) is the most accurate; it is a method that unequivocally defines the reproductive phase of the animal (Barber and Blake, 2006).

Sastry (1963) described four reproductive stages for Argopecten ventricosus: (1) immature; (2) partially mature; (3) mature; and (4) spent. Villalejo-Fuerte and Ochoa (1993) and Benninger and LePennec (1991) described the following stages for this same species: (1) initial gametogenesis; (2) advanced gametogenesis; (3) mature; (4) spawning; and (5) spent.

However Barber and Blake (1991) described six reproductive stages for molluscs (including pectinids): (1) spent (vegetative reproductive period); (2) cellular differentiation; (3) cytoplasmatic growth; (4) vitelogenesis (maturation); (5) spawning; and (6) reabsorption of leftover gametes. These authors, Barber and Blake (2006), in 2006 wrote that the pectinid Pecten maximus displays seven stages, those being: (0) immature; (1) development; 


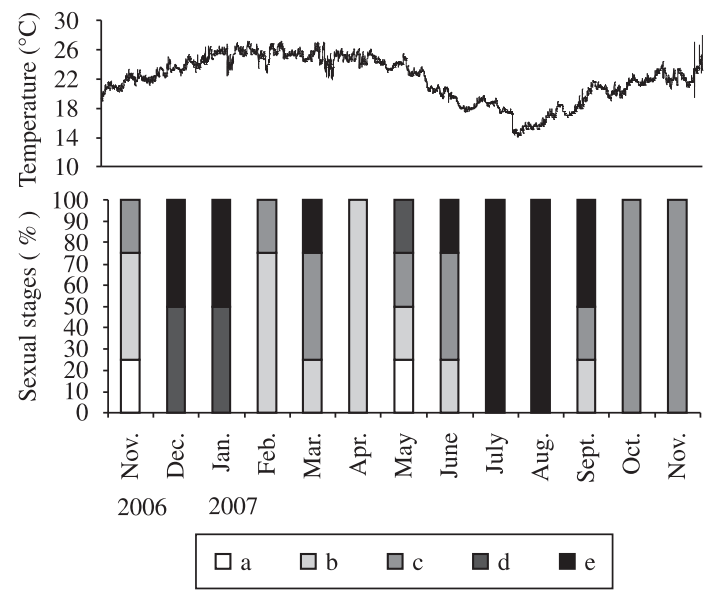

Figure 2. Temperature of the sea water during the experiment and the maturation stages of the animals ( $N$. nodosus) determined monthly $(\mathrm{n}=4)$. Stages: (a) gametogenesis; (b) initial pre-spawning; 09(c) advanced pre-spawning; (d) initial spawning; (e) advanced spawning.

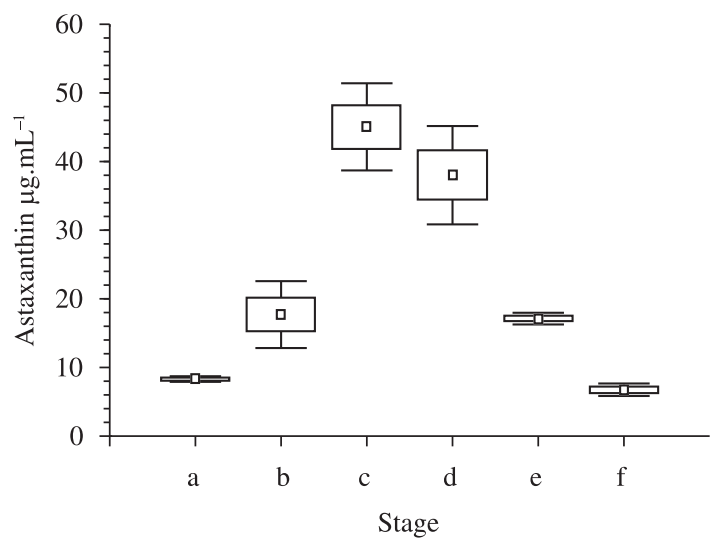

工 \pm Esd. Des. $\square \pm$ Est. Err $\square$ Mean

Figure 3. Astaxanthin quantity in the female portion of the scallop N.nodosus gonad in the four stages of the reproductive cycle: (a) gametogenesis; (b) initial prespawning; (c) advanced pre-spawning; (d) initial spawning; (e) advanced spawning; (f) spent.

(2) differentiation; (3) recovery; (4) swelling; (5) initial maturation; (6) advanced maturation; and (7) partial or total spawning.

According to Penchaszadeh et al. (2000), the pectinid Amusium laurenti has four sexual stages, these being: (1) follicle development; (2) full follicle; (3) partial spawning; and (4) total spawning. This author does not describe the stage of spent for this species.

According to Freitas (2001) the reproductive cycle of the $N$. nodosus scallop has three distinct phases with the following characteristics: (1) spent, at this stage it is not possible to distinguish the male or female portions of the gonad; (2) follicle organisation and sex cell multiplication;
(3) reproductive period, which includes the gonad maturation, gamete elimination and gonad restoration.

Individual $N$. nodosus scallops with $50 \mathrm{~mm}$ in height (approximately 6-7 months after hatching) are already sexually mature and able to reproduce (Freitas, 2001). For this phase, (phase 3 - reproductive period) our work identified four distinct reproductive stages, where the $2^{\text {nd }}$ and $3^{\text {rd }}$ stages were subdivided into $\mathrm{A}$ and $\mathrm{B}$.

The four reproductive stages presented in this work were adopted because they are easy to recognise, even when we consider the dynamic aspects of the reproductive cycle of Nodipecten nodosus.

Differentiation between the four stages described in this study was based on microscopic evaluation of each stage. This division into stages is particularly useful in the process of captive breeding in nurseries, as it facilitates the identification of the favourable reproductive stages of broodstock to be used for seed production. In captivity, after $N$. nodosus are collected from the sea, the animals go through a period of maturation when they are kept in tanks and fed daily. The quality of this feed is important for the success of maturation and later production of viable larvae.

In our macroscopic evaluation and description of $N$. nodosus, gonads that are not significantly swollen, a pale orange colour, and visible granules characterise the stage of gametogenesis. No macroscopic differentiation was observed for the stages of initial pre-spawning (Stage 2A) and advanced pre-spawning (Stage 2B); both stages presented swollen gonads, bright orange coloration and no granules. Differences between these two sub-stages could only be detected under the microscope. The stages of initial spawning (Stage 3A) and advanced spawning (Stage 3B) also showed no macroscopic difference, both showed apparently swollen gonads, bright orange coloration and granules. For the spent stage (Stage 4) the gonad was not swollen, and presented an opaque, very pale orange colour without granules.

The spent stage (Stage 4) described in this study was also noted by Manzoni et al. (1996) for $N$. nodosus over the winter; however, it was not commented on by Freitas (2001) in a study of the same species. Luna-González (1997) and Luna-González et al. (2000) observed that the spent stage for Argopecten ventricosus in Mexico occurred during the month of July.

In some bivalves, during the spent stage the connective tissue surrounds the follicles, and spreads and expands according to the level and degree of gamete maturation (Lunetta, 1969; Calvo, et al. 1998). This is why connective tissue fills the empty inter-follicle spaces in the spent stage when there are only a few leftover gametes.

The spawning period for $N$. nodosus observed in this study, with higher seawater temperatures over the summer period, was also observed for other species of pectinids from a temperate climate, such as Amusium laurenti (Penchaszadeh et al., 2000). For Pecten maximus in Galicia (Pazos et al., 1996), the spawning period is most intense 
during the winter $\left(12.0\right.$ to $\left.12.7^{\circ} \mathrm{C}\right)$ and spring, when the temperature reaches $16{ }^{\circ} \mathrm{C}$.

According to Manzoni et al. (1996), N. nodosus of the Arvoredo Island show partial and asynchronous spawning throughout the year. However, this does not automatically imply that the animals are spawning viable gametes, rather that they may be simply expelling gametes due to environmental stress factors, such as temperature. The same authors observed that the period between November and December presented the highest gonadosomatic index, and this is associated with high water temperatures.

In the present study, the histological evaluation of the maturation stage throughout the year in a cultivation environment, two distinct spawning seasons were observed, one in the summer (December and January) and another at the end of winter and the beginning of spring (July to September). These winter and spring spawning peaks with lower seawater temperatures were also observed by Manzoni and Banwart (2000).

To evaluate the relation of carotenoid quantity with reproductive stage, the levels of the carotenoid astaxanthin were measured in the female part of the gonad. This analysis indicated that during the advanced pre-spawning and initial spawning stages there are higher levels of astaxanthin in the female portion of the gonad than in gametogenesis, initial pre-spawning, advanced spawning, and spent the stages.

The highest carotenoids concentration at the advanced pre-spawning (Stage 2B) suggests that carotenoids are accumulated in the oocytes and not in the interfollicular tissue. This is because the spent stage (Stage 4), which has a large amount of connective tissue (inter-follicle tissue) and few remaining oocytes, is the smallest amount of carotenoids in the stages of the reproductive cycle for this species.

According to Farías-Molina (2001), carotenoids are required for gonad development and gamete maturation in invertebrates. For other species of aquatic animals, like shrimp (Lorenz, 1998; Howell and Matthews, 1991; Cuzon et al., 2004) and fish (Meyers, 1994), the carotenoids showed a positive effect on maturation and reproduction.

The higher astaxanthin quantity during the advanced pre-spawning and initial spawning stages suggests that carotenoid accumulation is correlated to oocyte maturation. However, further studies are needed to evaluate the effect of carotenoids on reproduction and survival of molluscs larvae.

As the bivalve molluscs are unable to synthesise carotenoids (Johnson and Schroeder, 1995; Farías-Molina, 2001), our study suggests that their absorption through a diet rich in phytoplankton carotenoids is important for good reproductive results.

The reserves for the early embryonic development of the bivalve molluscs are found in the oocyte cytoplasm. The eggs of molluscs are small (about $50 \mu \mathrm{m}$, according to Mackie, 1984), with little calf, allowing a total cleavage, type holoblastic spiral. However, the calf needs to ensure the development of the embryo, without an external food source, to form a larvae that swims and feeds. Carotenoids also compose this vitelline reserve of molluscs eggs.

In mussels Perna perna (Linné, 1758), according to Lunetta (1969), a salmon or orange-yellow colour in the oocytes is related to a lipid inclusion. On the other hand, in $N$. nodosus this colour can be related to both the lipid influence and presence of carotenoids in the oocytes, other evidence of this relationship is the fat-soluble carotenoids property.

As demonstrated by the results of our work, it is possible to establish a very close relation between the stages of the reproductive cycle and the astaxanthin content in the female portion of the gonad during the maturation and spawning processes of $N$. nodosus. This study also observed, for the captive environment, similar periods for reproductive peaks as those observed in the natural environment.

Acknowledgements - We are thankful to FINEP, FAPESC and $\mathrm{CNPq}$ for financial support and to CAPES/UFSC for a $\mathrm{PhD}$ scholarship.

\section{References}

BARBER, BJ. and BLAKE NJ., 1991. Reproductive physiology. In SHUMWAY, SE. (Ed.). Scallop: biology, ecology and aquaculture. Amsterdam: Elsevier.

BARBER, BJ. and BLAKE, NJ., 2006. Reproductive physiology. In SHUMWAY, SE. and PARSONS, GJ. (Eds.). Scallops: biology, ecology and aquaculture. 2 ed. Amsterdam: Elsevier. p. 357-415. (vol. 35)

BENNINGER, PG. and LEPENNEC, M., 1991. Functional anatomy of scallops. In SHUMWAY, SE. (Ed.). Scallop: biology, ecology and aquaculture. Amsterdam: Elsevier. p. 133-223.

CALVO, J., MORRICONI, E. and ORLER, PM., 1998. Estratégias reproductivas de moluscos bibalves y equinoideos. El Mar Argentino y sus Recursos Pesqueros, vol. 2, no. 2, p. 195-231.

CUZON, G., LAWRENCE, A., GAXIOLA, G., ROSAS, C. and GUILLAUME, J., 2004. Nutrition of Litopenaeus vannamei reared in tanks or in ponds. Aquaculture, vol. 235, no. 1-4, p. 513-551.

Empresa de Pesquisa Agropecuária e Extensão Rural de Santa Catarina - EPAGRI, 2008. Cultivo da vieira Nodipecten nodosus em Santa Catarina: influência da profundidade, densidade e frequência de limpeza. Florianópolis. Boletim Técnico, 135. Available from: $<$ http://www.epagri.rct-sc.br/>. Access in: 08/10/2009.

Food and Agriculture Organization - FAO, 2009. Fishery and aquaculture statistics. Rome. Available from: <http://www.gfcm. org/figis/servlet/SQServlet?file=/usr/local/tomcat/FI/5.5.23/figis/ webapps/figis/temp/hqp_3713.xml\&outtype $=\mathrm{html}>$. Access in: 08/10/2009.

FARÍAS-MOLINA, A., 2001. Nutrición en moluscos Pectínidos. In MAEDA-MARTINZ, AN. (Ed.). Los Moluscos Pectínidos de Iberoamérica: ciencia y acuicultura. México: Editora Limusa. p. 89-104.

FREITAS, CA., 2001. Formação da gônada e índice Gonádico em juvenis da vieira Nodipecten nodosus (Linnaeus, 1758) (Bivalvia: Pectinidae) cultivados em diferentes profundidades. Florianópolis: Universidade Federal de Santa Catarina. 33 p. [Dissertação de Mestrado] 
JOHNSON, EA. and SCHROEDER, WA., 1995. Microbial carotenoids. In FIECHTER, A. (Ed.). Advances Biochemical Engineering and Biotechnology. Berlin: Springer-Verlag. p. $119-178$.

HOWELL, BK. and MATTHEWS, AD., 1991. The carotenoids of wild and blue disease affected farmed tiger shrimp (Penaeus monodon fabricus). Comparative Biochemistry and Physiology, vol. 98B, no. 2-3, p. 375-379.

LODEIROS, CJ., RENGEL, JJ., FREITES, L., MORALES, F. and HIMMELMAN, JH., 1997. Growth and survival of the tropical scallop Lyropecten (Nodipecten) nodosus maintained in suspended culture at three depths. Aquaculture, vol. 165, no. 1-2, p. 41-50.

LORENZ, TA., 1998. Review of the Carotenoid, Astaxanthin, as a Pigment and Vitamin Source for Cultured Penaeus Prawn. Kailua-Kona (Hawaii): NatuRose. Available from: <www. cyanotech.com>. Access in: 01/05/2008.

LUBET, P., 1959. Recherches sur le cycle sexuel et l'émission des gamètes chez les mytilides et les pectinides (Mollusques Bivalves). Revue des travaux de l'Institut des peches maritimes, vol. 23 , no. 4 , p. $387-548$

LUNA-GONZALEZ, A., 1997. Ciclo reproductivo de la almeja catarina Argopecten ventricosus (Sowerby II, 1842), cultivada en la rada del puerto de Pichilingue, B.C.S. u su relación con el medio. México: Universidad Autónoma de Baja California Sur. 74 p. [Dissertação de Mestrado]

LUNA-GONZALES, A., CÁCERES-MARTÍNEZ, C., ZÚÑIGAPACHECO, C., LÓPEZ-LÓPEZ and CEBALLO-VÁZQUEZ, P., 2000. Reproductive cycle of Argopecten ventricosus (Sowerby, 1842) (Bivalvia: Pectinidae) in the Rada del Puerto de Pichiligüe, B.C.S., México and its relation to temperature, salinity and food. Journal of Shellfish Research, vol. 19, no. 1, p. 107-112.

LUNETTA, JE., 1969. Fisiologia da reprodução de mexilhões (Mytilus perna L. Mollusca Lamellibranchia). Boletim de Zoologia e Biologia Marinha, vol. 26, n. 324, p. 33-111.

MACKIE, GL., 1984. Bivalves. In TOMPA, AS., VERDONK, NH. and BIGGELAAR, JAM. (Eds.). The Mollusca. Orlando: Academic Press. p. 351-418. (vol. 7).

MANZONI, GC. and RUPP, GS., 1993. Estudo da biologia reprodutiva e viabilidade de cultivo de Lyropecten nodosus (Linnaeus, 1758) (Mollusca: Pectinidae) na Ilha do Arvoredo$S C$. Florianópolis: Universidade Federal de Santa Catarina. $35 \mathrm{p}$ (Relatório final).

MANZONI, GC., 1994. Aspectos da biologia de Nodipecten nodosus, (Linnaeus, 1758) (Mollusca: Bivalvia), nos arredores da ilha do Arvoredo (Santa Catarina - Brasil), com vistas a sua utilização na aqüicultura. Florianópolis: Universidade Federal de Santa Catarina. 98 p. [Dissertação de Mestrado]

MANZONI, GC., POLI, CR. and RUPP, GS., 1996. Período reproductivo del pectínido Nodipecten nodosus (Mollusca: Bivalvia) en los alrededores de la Isla Arvoredo (27 $17^{\prime} \mathrm{S}-48^{\circ}$ 22'W) - Santa Catarina, Brasil. In SILVA, A. and MERINO, G. (Eds.). Acuicultura en Latinoamérica: Anais do IX Congresso Latinoamericano de Acuicultura. Chile: Universidad Católica del Norte. p. 197-201.
MANZONI, GC. and BANWART, JPF., 2000. Aspectos da biología reprodutiva da vieira Nodipecten nodosus, cultivada na enseada da Armação do Itapocoroy (26046' S - 480 37' W) (Penha - SC). In Anais da XIII Semana Nacional da Oceanografia. Itajaí: Editora da Univalli. p. 537-539.

MEYERS, PS., 1994. Developments in World aquaculture, feed formulation and role of carotenoids. Pure and Applies Chemistry, vol. 66, no. 5, p. 1069-1076.

OSTINI, S. and POLI, CR., 1990. A situação do cultivo de moluscos no Brasil. In HERNANDEZ, RA. (Ed.). Cultivo de moluscos en América Latina. Bogotá: Ed. Guadalupe. p. 311-325.

PAZOS, AJ., RÓMAN, G., ACOSTA, CP., ABAD, M. and SÁNCHEZ, JL., 1996. Stereological studies on hte gametogenic cycle of the scallop, Pecten maximus, in suspended culture in Ria de Arousa (Galicia, NW Spain). Aquaculture, vol. 142, no. 1-2, p. $119-135$

PENCHASZADEH, PE., PAREDES, C. and SALAYA, JJ., 2000. Reproductive cycle of the south American scallop Amusium laurenti (Gmelin, 1791) (Bivalvia, Pectinidae). Aquaculture International, vol. 8, no. 2-3, p. 227-235.

RIOS, EC., 2009. Compendium of brazilian sea shells. Rio Grande: Evangraf. 668 p

ROMÁN, G., MARTÍNEZ, G., GARCÍA, O. and FREITES, L., 2001. Reproducción. In MAEDA-MARTINZ, AN. (Ed.). Los Moluscos Pectinídeos de Iberoamérica: ciência y acuicultura. México: Editora Limusa. p. 27-59.

RUPP, GS., 1994. Obtenção de reprodutores, indução à desova e cultivo larval e pós-larval de Nodipecten nodosus (Linnaeus, 1758) (Bivalvia: Pectinidae). Florianópolis: Universidade Federal de Santa Catarina. 125 p. [Dissertação de Mestrado]

RUPP, GS., THOMPSON, RJ., PARSONS GJ. and BEM, MM., 2004. Influence of food supply on postmetamorphic growth and survival of hatchery-produced lion's paw scallop, Nodipecten nodosus (Linnaeus, 1758). Journal of Shellfish Research, vol. 23 , no. 1 , p. 5-13.

RUPP, GS. and PARSONS, GJ., 2006. Scallop aquaculture and fisheries in Brazil. In SHUMWAY, SE. and PARSONS, GJ. (Eds.). Scallops: biology, ecology and aquaculture. Amsterdam: Elsevier.

SASTRY, AN., 1975. Physiology and ecology of reproduction in marine invertebrates. In VERMBERG, FJ. (Ed.). Physiological ecology of estuarine organisms. Columbia: University of South Carolina Press. p. 279-299.

SÜHNEL, S., LAGREZE, F., FERREIRA, JF., CAMPESTRINI, LH. and MARASCHIN, M., 2009. Carotenoid extraction from the gonad of the scallop Nodipecten nodosus (Bivalvia: Pectinidae). Brazilian Journal Biology, vol. 69, no. 1, p. 209-215.

VILLALEJO-FUERTE, M. and OCHOA, RI., 1993. The reproductive cycle of the scallop Argopecten circularis (Sowerby, 1835) in relation to temperature and photoperiod, in Bahia Concepcion, B.C.S. Mexico. Ciencias Marinas, vol. 19, no. 2, p. 181-202.

ZAR, JH., 1974. Biostatistical analyses. Englewood Cliffs: Prentice-Hall. 357 p. 